\title{
Decreased expression of the thyroid-stimulating hormone receptor in poorly-differentiated carcinoma of the thyroid
}

\author{
HIROFUMI MATSUMOTO $^{1}$, ATSUHIKO SAKAMOTO ${ }^{1}$, MASACHIKA FUJIWARA ${ }^{1}$, \\ YUKIKO YANO $^{2}$, YUKIKO SHISHIDO-HARA ${ }^{1}$, YASUNORI FUJIOKA ${ }^{1}$ and HIROSHI KAMMA ${ }^{1}$ \\ ${ }^{1}$ Department of Pathology, Kyorin University School of Medicine, Tokyo 181-8611; ${ }^{2}$ Ito Hospital, Tokyo 150-8308, Japan
}

Received October 22, 2007; Accepted December 3, 2007

\begin{abstract}
Poorly-differentiated carcinomas (PDCs) occupy an intermediate position between differentiated (follicular and papillary) and undifferentiated carcinomas (UDCs) based on morphology and behavior. However, its definition remains unclear, especially in the differentiation of thyroid function. To characterize the hormonal differentiation of PDCs, in addition to the morphological definition, we immunohistochemically investigated the thyroid-stimulating hormone receptor (TSHR) and thyroid transcription factor 1 (TTF-1) as regulators of thyroid hormonal function and differentiation. We comparatively studied their expression in 15 papillary carcinoma (PTC), 8 PDC and 8 UDC cases and further analyzed their correlation to proliferation activity as estimated by the MIB-1 index. All cases of PTC and PDC expressed the TSHR, whereas all cases of UDC did not. Notably, most of the PDCs showed more decreased and heterogeneous expression in the poorly-differentiated component than in the welldifferentiated one within the same case. Examining the heterogeneous areas in PDC, we found an inverse relationship between TSHR expression and the MIB-1 index, that is, decreased TSHR expression was correlated to high proliferation. Unexpectedly, TTF-1 expression was observed in almost all of the PTC and PDC cases and in half of the UDC cases; therefore, it was not useful to distinguish PDC from PTC or UDC. In conclusion, we demonstrated that TSHR expression was decreased in PDCs despite conserved TTF-1 expression and that it correlated to the proliferative activity in PDCs.
\end{abstract}

\section{Introduction}

Among thyroid neoplasms, poorly-differentiated carcinomas (PDCs) are regarded as a distinct group of tumors which

Correspondence to: Dr Hiroshi Kamma, Department of Pathology, Kyorin University, School of Medicine, 6-20-2 Shinkawa, Mitaka, Tokyo 181-8611, Japan

E-mail: hkamma@kyorin-u.ac.jp

Key words: thyroid-stimulating hormone receptor, thyroid carcinoma occupy an intermediate histological and behavioral position between follicular-derived well-differentiated and undifferentiated carcinomas (UDCs), according to the World Health Organization (WHO) Classification of Tumors 2004.

The identification of PDC can be traced back to the original concepts, which were independently and almost simultaneously proposed by Sakamoto et al (1) and Carcangiu et al (2). Sakamoto et al based their proposal exclusively on the pattern of growth, which they identified as a solid, trabecular and scirrhous pattern. Carcangiu et al described a tumor with a distinctive set of architectural and cytological features, which included an insular pattern of growth, small cell size, round hyperchromatic nuclei, mitotic activity and frequent necrosis. Certain authors criticized the idea of identifying PDC based on the growth pattern only and pointed out that PDCs are characterized by high-grade histology with atypia, a high mitotic count and necrosis $(3,4)$. This controversy indicates that biological characterization from other viewpoints besides growth pattern is needed.

Differentiation refers to the extent to which neoplastic cells resemble normal cells, morphologically and functionally. Thus, some of the thyroid-specific proteins related to hormone synthesis were investigated as functional differentiation markers in thyroid neoplasms (e.g. thyroglobulin, $\mathrm{Na}^{+} / \mathrm{I}$ symporter, thyroperoxidase and pendrin). However, the expression of these proteins is decreased or absent in differentiated thyroid carcinoma (5-10); therefore, they are not useful as a functional differentiation marker for PDC.

Of note, the thyroid-stimulating hormone receptor (TSHR), which is a $G$ protein-coupled receptor regulating thyroid cell proliferation as well as hormone synthesis and the thyroid transcription factor 1 (TTF-1), a transcription factor which binds to the TSHR minimal promoter (11), are always detectable in differentiated carcinoma. In contrast, they are always absent in UDC (12,13). For this reason, an immunohistochemical examination of TSHR and TTF-1 represented a marker of functional differentiation in PDC. Examining the growth activity by using an antibody to MIB-1, a nuclear antigen expressed in the G1, S, G2 and M phases of the cell cycle and clarifying the correlation of the MIB-1 index and TSHR expression would increase our understanding of the basic biological mechanisms underlying cell proliferation in thyroid carcinoma.

The objective of our study was to define the functional differentiation of PDC from the standpoint of TSHR expression 
and to clarify the relationship between TSHR expression and tumor cell proliferation.

\section{Materials and methods}

Histological examination. A series of histological specimens from patients with thyroid carcinoma comprised of papillary carcinoma (PTC) (15 cases), PDC (8 cases) and UDC (8 cases) were selected from the surgical pathology files of Kyorin University Hospital, Tsukuba University Hospital and Kuma Hospital. Each specimen was fixed in $10 \%$ neutral formalin, processed routinely, embedded in paraffin wax, sectioned at four-microns thick and stained with $\mathrm{H} \& \mathrm{E}$.

Each specimen was re-evaluated by three pathologists (H.M., H.K. and A.S.) according to the WHO classification.

Immunohistochemistry. For immunohistochemical analysis, the following antibodies were used: mouse anti-human TSHR monoclonal antibody (Serotec, Kidlington, Oxford, UK, clone: 4C1) binding to the extracellular domain, mouse anti-TTF-1 monoclonal antibody (DakoCytomation, clone: 8G7G3/1) and mouse anti-human Ki-67 antibody (MIB-1; DakoCytomation, clone: MIB-1), all at a dilution of 1:100. A heat-induced epitope retrieval technique was applied for TTF-1 and MIB-1. Immunohistochemical staining was performed using an automated immunostainer (Ventana Inc, Tucson, AZ). The tissue was counterstained with hematoxylin. Appropriate negative controls consisted of tissue sections of each case processed without the addition of a primary antibody. Moreover, in order to confirm TSHR immunostaining, we used a mouse anti-human TSHR monoclonal antibody (Novocastra, Newcastle, UK), according to a previously published procedure (14).

Each of the immunohistochemical slides were independently evaluated by three of the authors (H.M., H.K. and A.S.) without knowledge of the pathological parameters. If there was any discordance in the assessments, they were settled by discussion between the observers. Immunoreactivity for TSHR was evaluated by comparing the intensity of positive staining of normal thyroid tissues in each sample. In case there was no normal tissue in the PDC and UDC specimens, it was evaluated by comparison with that of the differentiated carcinoma component. Immunoreactivity for TTF-1 was evaluated in terms of the number of carcinoma cells with nuclear staining: $(+),<20 \%$; (++), 20-50\%; (+++), >50\%. To evaluate the MIB-1 index, cells with distinct brown nuclear staining were scored as positive and MIB-1 immunoreactivity was described as the percentage of positive nuclei. More than 1000 cells in the specimen were counted in photographs, which were taken from randomly selected areas of the lesion. The significance of the differences in the MIB-1 index was tested by using the Student's t-test. The criterion for significance was $\mathrm{p}<0.05$.

$R T-P C R$. RNA was isolated from thyroid tumor tissues embedded in paraffin blocks. With reference to H\&E-stained sections, the appropriate area of the tumor was selected and five $(10 \mu \mathrm{m})$ sections of the selected area were cut using a microtome, placed in a sterile $1.5 \mathrm{ml}$ microcentrifuge tube and deparaffinized at room temperature with xylene and $100 \%$ ethanol. After air drying, the pellets were re-suspended in $130 \mu 1$ of extraction buffer ( $20 \mathrm{mM}$ Tris- $\mathrm{HCl}, \mathrm{pH} 8.0 ; 20 \mathrm{mM}$ EDTA; $2 \%$ sodium dodecyl sulfate) and $20 \mu 1$ of $2.67-5.34 \mathrm{mg} /$ $\mathrm{ml}$ proteinase $\mathrm{K}$ and then incubated at $55^{\circ} \mathrm{C}$ overnight. Total RNA was isolated using Isogen-LS (Nippon Gene, Tokyo, Japan) and reverse-transcribed using the Takara RNA PCR kit Ver.3.0 (Takara, Ohtsu, Japan) according to the manufacturer's instructions. PCR was carried out for TSHR mRNA using the following primers: TSHR-forward 5'-CCC GCTTACCGCCCAGT-3', TSHR-reverse 3'-TAGAAAATG CATGACTTGGAATAGTTC-5' (78 bp) (15); ß-actin, a control gene ubiquitously expressed, was also analyzed to confirm the success of RNA extraction. Aliquots $(1 \mu \mathrm{l})$ of the reverse transcription products were amplified in $20 \mu 1$ of a reaction buffer containing $15.3 \mu 1$ of distilled water, $2 \mu 1$ of $10 \times$ PCR buffer (Takara), $2 \mu 1$ of $2.0 \mathrm{mM}$ deoxynucleotide triphosphates, $0.3 \mu \mathrm{l}$ of $20 \mu \mathrm{M}$ each primer and $0.1 \mu 1$ of Taq polymerase (Promega). PCR conditions were $94^{\circ} \mathrm{C}$ for $2 \mathrm{~min}$, followed by 45 cycles of $94^{\circ} \mathrm{C}$ for $50 \mathrm{sec}, 60^{\circ} \mathrm{C}$ for $30 \mathrm{sec}$ and $72^{\circ} \mathrm{C}$ for $60 \mathrm{sec}$, followed by a final extension at $72^{\circ} \mathrm{C}$ for $4 \mathrm{~min}$. RT-PCR products were resolved on $5 \%$ polyacrylamide and visualized by ethidium bromide staining.

\section{Results}

Expression of TSHR immunohistochemically detected in thyroid carcinomas. Positive cases were classified into two groups: the slightly positive group, in which the stained intensity of the tumor was weaker than that of the normal thyroid or the differentiated carcinoma component in the same patient and the strongly positive group, in which the intensity was almost the same as or higher than the criterion of each case. Regardless of proportion, if a slightly positive component was observed, we classified the case into the slightly positive group.

All PTC and 1 of 8 PDC cases belonged to the strongly positive group (Fig. 1A). Positive staining was distributed in a patchy manner in the cytoplasm. In certain cases, a strong stain appeared along the edge of the cytoplasm. Seven out of 8 PDC cases belonged to the slightly positive group (Fig. 1B). The PDC component consisted of slightly TSHR-stained areas and strongly stained areas in various proportions. All of the 8 UDC cases were negative for TSHR (Fig. 1C).

$R T-P C R$. To confirm the immunohistochemical results of TSHR expression, we performed RT-PCR analysis of TSHR expression in representative cases of 2 PTC, 2 PDC, and 1 UDC. The PTC and PDC cases resulted in the amplification of the predicted $78 \mathrm{bp}$ band corresponding to the TSH-R (Fig. 2). This band could not be detected in the UDC case (Fig. 2).

TTF-1 reactivity of thyroid carcinoma. We examined the relationship between TSHR and TTF-1 expression. Each PTC and 7 of the 8 PDC cases showed high TTF-1 reactivity (+++) regardless of TSHR expression. One of 7 PDC cases, which belonged to the slightly positive group, showed TTF-1 reactivity $(+$ to +++ ) that was correlated with TSHR expression. Four of the 8 UDC cases showed TTF-1 reactivity (++ to +++ ) (Fig. 3), while the other four cases showed no 

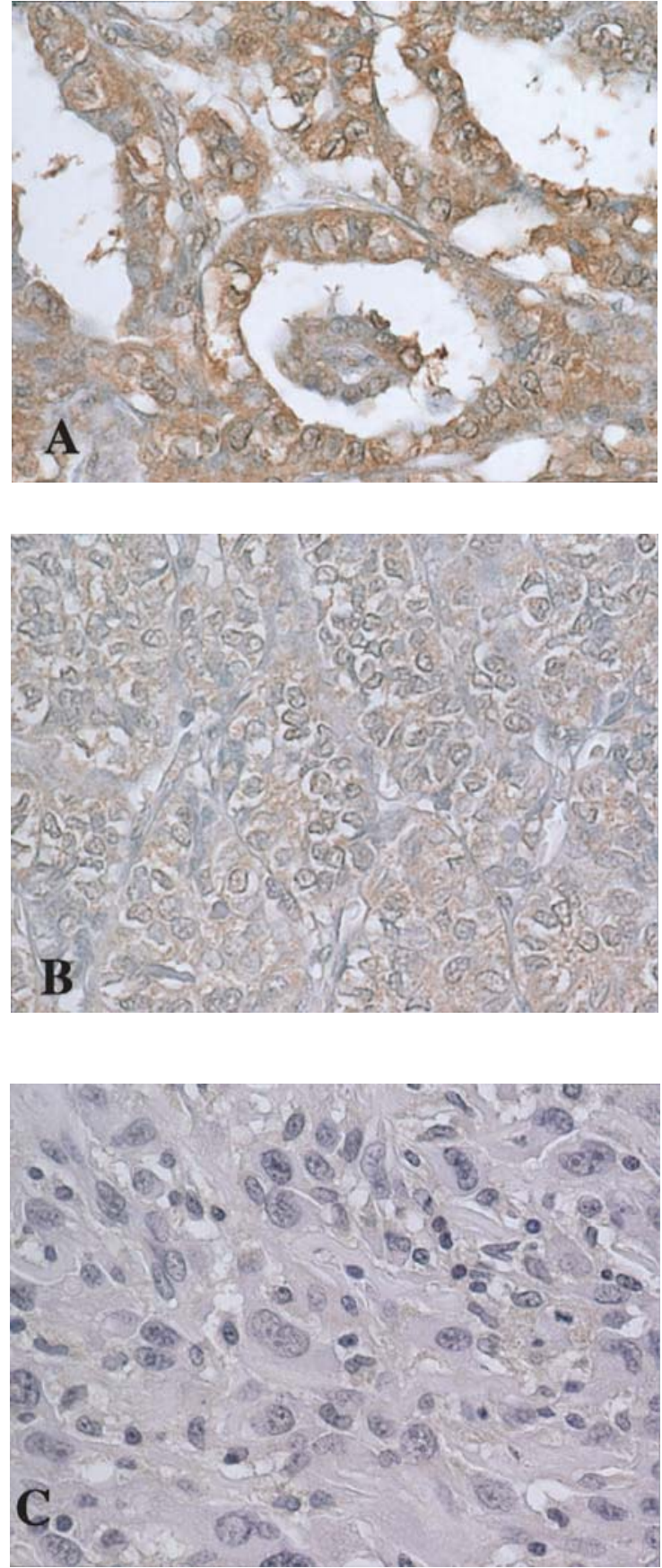

Figure 1. The expression of TSHR in thyroid carcinomas. In PTC, TSHR staining was observed near the membrane, though positive staining occurred in the cytoplasm (A). The intensity of the staining was decreased in PDC (B). UDC did not express TSHR (C).

reactivity. Table I shows the TTF-1 reactivity of PDC and UDC.

The relationship between TSHR expression and the MIB-1 index of $P D C$. For a comparison of TSHR expression and growth activity, we estimated the MIB-1 index in 7 PDC cases of the slightly positive group. In 5 of the 7 PDC cases, the MIB-1 index in the slightly positive TSHR expression areas was significantly higher than that in the strongly positive expression areas (Fig. 4, Table II).

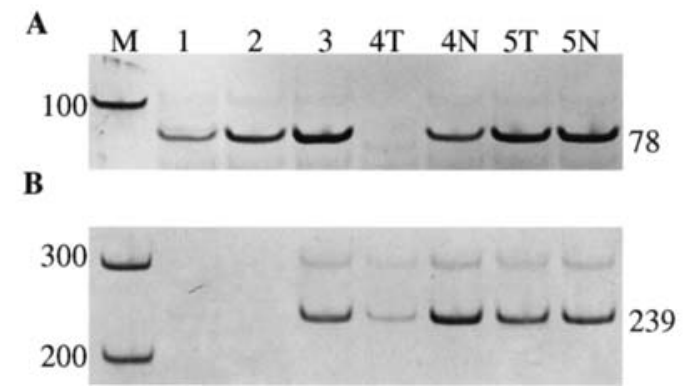

Figure 2. PCR detection of the TSHR (A) and B-actin (B). Lane 1, PDC case (i); lane 2 PDC case (i); lane 3, PTC case (ii); lane 4T, undifferentiated component of UDC case (i); lane 4N, normal thyroid component of UDC case (i); lane 5T, solid component of PDC case (ii); lane 5N, normal thyroid component of PDC case (ii); lane M, 100 base pair.
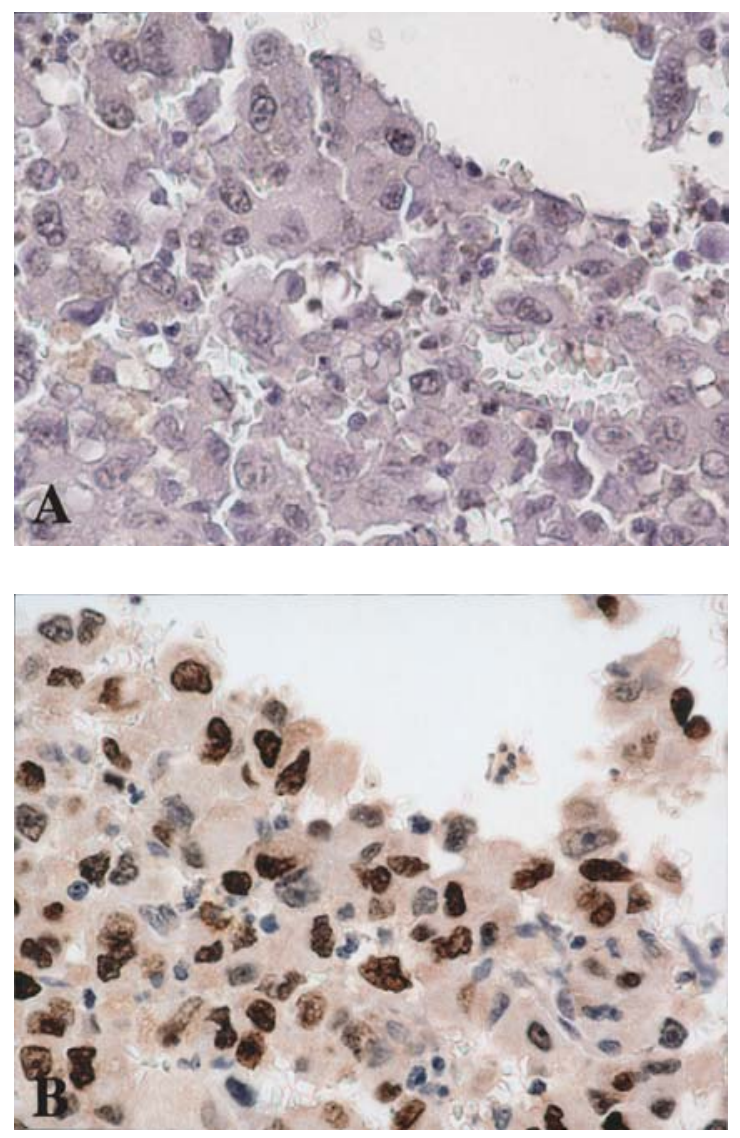

Figure 3. TTF-1-positive case in UDC. The case of UDC with a TSHR negative area (A), which showed strong TTF-1 expression (B).

\section{Discussion}

In order to summarize the results of this study, we immunohistochemically demonstrated that each of the PTC and PDC cases exhibited TSHR expression, whereas all cases of UDC did not show TSHR expression. This was confirmed by RT-PCR analysis. Notably, most PDC cases showed a heterogeneous and weaker expression of TSHR than PTC cases. In the cases of heterogeneous expression in PDC, the degree of TSHR expression was correlated with proliferation activity as estimated by the MIB-1 index. Unexpectedly most 
Table I. TTF-1 reactivity of PDC and UDC.

\begin{tabular}{|c|c|c|c|c|}
\hline \multirow[b]{2}{*}{ Case No. } & \multicolumn{4}{|c|}{ TTF-1 expression } \\
\hline & WDC & $\begin{array}{c}\text { TSHR strong } \\
\text { expression area in STI }\end{array}$ & $\begin{array}{c}\text { TSHR weak } \\
\text { expression area in STI }\end{array}$ & TSHR negative area \\
\hline \multicolumn{5}{|l|}{ PDC } \\
\hline 1 & $(+++)$ & - & $(+++)$ & - \\
\hline 2 & $(+++)$ & $(+++)$ & - & - \\
\hline 3 & - & $(+++)$ & $(+++)$ & - \\
\hline 4 & $(+++)$ & - & $(+++)$ & - \\
\hline 5 & - & $(+++)$ & $(+++)$ & - \\
\hline 6 & $(+++)$ & $(++)$ & $(+)$ & - \\
\hline 7 & - & $(+++)$ & $(+++)$ & - \\
\hline 8 & $(+++)$ & $(+++)$ & $(+++)$ & - \\
\hline \multicolumn{5}{|l|}{ UDC } \\
\hline 9 & $(+++)$ & - & - & $(++)$ \\
\hline 10 & - & - & - & $(-)$ \\
\hline 11 & - & - & - & $(-)$ \\
\hline 12 & - & - & - & $(-)$ \\
\hline 13 & $(+++)$ & - & $(+++)$ & $(+++)$ \\
\hline 14 & $(+++)$ & $(+++)$ & - & $(++)$ \\
\hline 15 & $(+++)$ & - & - & $(+++)$ \\
\hline 16 & - & - & - & $(-)$ \\
\hline
\end{tabular}

$(+),<20 \%$ positive tumor cells; $(++), 20-50 \%$ positive tumor cells; $(+++),>50 \%$ positive tumor cells. WDC, well-differentiated component; STI, solid-trabecular-insular component.

Table II. The relationship between TSHR expression and the MIB-1 index of PDC.

\begin{tabular}{lccc}
\hline & \multicolumn{2}{c}{ MIB-1 index $(\%)^{\mathrm{a}}$} \\
\cline { 2 - 4 } Case No. & WDC & TSHR strong expression area in STI & TSHR weak expression area in STI \\
\hline 1 & $0.30 \pm 0.17$ & - & $3.60 \pm 0.58^{\mathrm{b}}$ \\
2 & $0.34 \pm 0.23$ & $0.23 \pm 0.14$ & - \\
3 & - & $0.50 \pm 0.22$ & $5.50 \pm 0.51^{\mathrm{b}}$ \\
4 & $0.40 \pm 0.16$ & - & $2.20 \pm 0.43^{\mathrm{b}}$ \\
5 & - & $18.10 \pm 2.01$ & $17.50 \pm 1.41$ \\
6 & $0.20 \pm 0.34$ & $1.80 \pm 0.20$ & $7.40 \pm 0.27^{\mathrm{b}}$ \\
7 & - & $2.90 \pm 0.40$ & $3.80 \pm 0.52$ \\
8 & $0.30 \pm 0.24$ & $1.80 \pm 0.44$ & $4.70 \pm 0.88^{\mathrm{b}}$
\end{tabular}

WDC, well-differentiated component; STI, solid-trabecular-insular component. ${ }^{\text {aV }}$ alues are mean \pm SD. ${ }^{b}$ Significant difference compared with TSHR strong expression area $(\mathrm{p}<0.05)$.

of the PDCs and half of the UDCs showed strong TTF-1 expression regardless of TSHR expression.

Immunohistochemically, we investigated the expression of TSHR in a series of thyroid carcinomas (PTC, PDC and UDC). TSHR expression was shown to occur in a patchy or diffuse cytoplasmic distribution, although the TSHR should theoretically be observed near the membrane. Certain authors have reported TSHR localized along the basal surface (14), while others reported it in the cytoplasm (16). Although we examined another antibody used in the previous reports $(6,14,16)$, there is no remarkable difference between these two antibodies. To confirm the antibody specificity, Western blotting was performed using normal thyroid tissue. This revealed that the antibody recognized two $70 \mathrm{kDa}$ bands and 

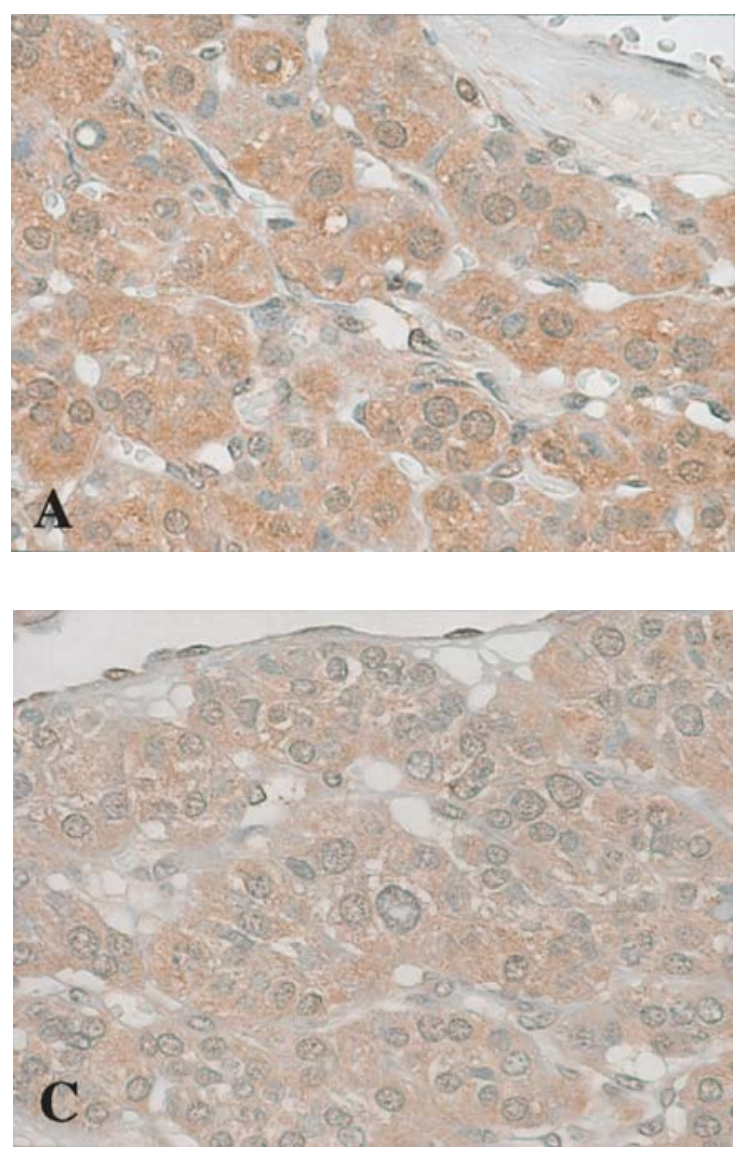
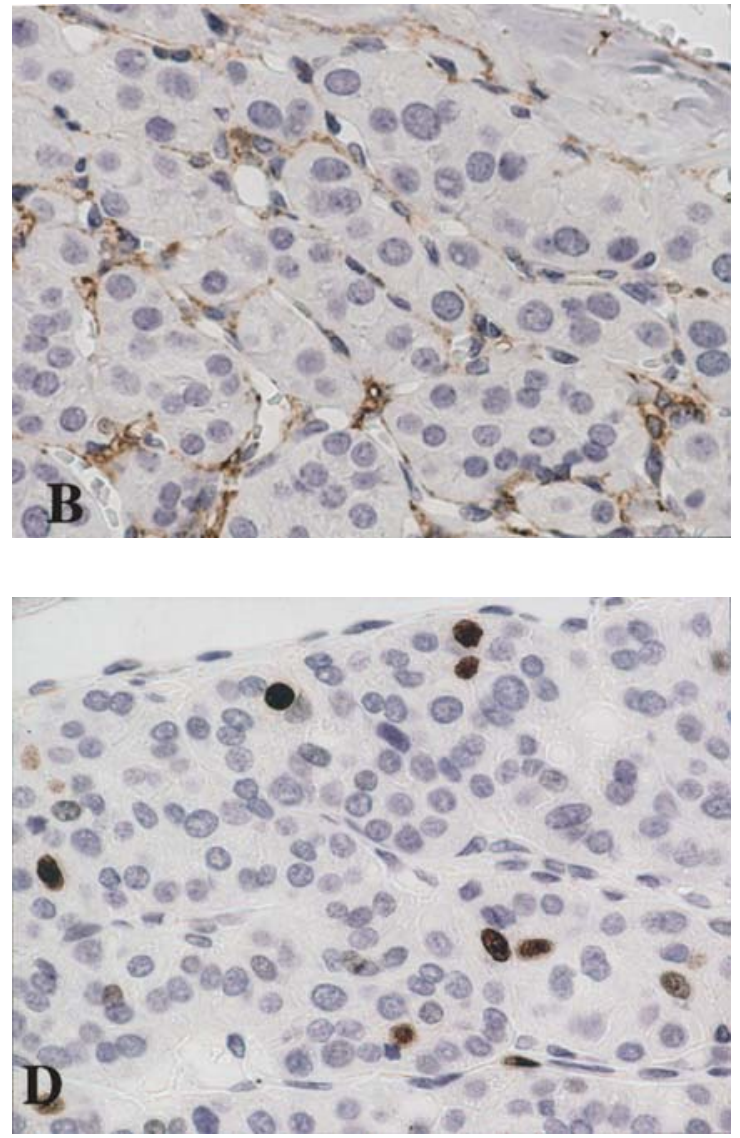

Figure 4. TSHR and MIB-1 expression in PDC. A case of PDC. Strong TSHR expression area (A) with MIB-1 expression (B). Weak TSHR expressing area (C) and its MIB-1 expression (D).

a band at $\sim 55 \mathrm{kDa}$, which corresponded to the cleaved TSHR (data not shown). In many receptor systems, one of the important events following ligand binding is internalization of the receptor-ligand complex (17). Consequently, TSH-TSHR complex internalization was suspected to be the underlying cause of cytoplasmic TSHR localization. All of the PTC and PCD cases showed TSHR expression, whereas all of the UDC cases did not. These findings are consistent with a previous study (14). Futhermore, in agreement with another previous finding (6), we demonstrated that the poorlydifferentiated components, such as trabecular, solid and insular ones, had decreased TSHR expression in most of the PDC cases. A previous study reported that clinically high-risk patients with PTC tended to show weaker TSHR staining than that of normal thyroid of the same patients (16). However, in the present study we found that the PTC cases did not show weaker staining than the PDC cases, which may indicate that the decline of TSHR expression affects the biological behavior of thyroid carcinomas. Notably, there was heterogeneous TSHR expression in poorly-differentiated components, which included strong staining and slightly stained areas. There are no previous studies which mention the heterogeneous distribution of TSHR expression in PDC. Furthermore, we analyzed the proliferation activity of PDC with heterogeneous TSHR expression and found that the MIB-1 index in areas of decreased TSHR expression was significantly higher than in strongly expressing areas. This finding suggests a correlation between decreased TSHR expression and the proliferation activity of thyroid carcinoma.

The regulation of tumor cell growth via the TSHR is not well understood. Some investigators have reported that the constitutive activation by point mutations of the $G_{a s}$ protein and the TSHR genes has been found in hyperfunctioning thyroid adenomas (18-20). However, these are not frequent events in the progression towards differentiated thyroid carcinomas (21). Moreover, some data suggest that cAMP acts as a growth inhibitor in some human thyroid tumor cell lines in vitro (22-25). These findings strongly suggest that the signaling pathways down stream of the TSHR participate in thyroid tumor progression. The decline in TSHR expression in PDC could affect the downstream signaling pathways. Most of the TSHR activities are mediated through a heterotrimeric Gs protein, which activates the adenylate cyclase-cAMP cascade (26-28). A previous study reported that in the differentiated carcinoma, the TSH responsiveness of adenylate cyclase was qualitatively similar to that of the normal thyroid and that the basal adenylate cyclase activity of UDC was significantly lower than that of the normal thyroid (29). It seems that the decrease of adenylate cyclase activity is due to the decreased expression of the TSHR.

In this study, we immunohistochemically investigated the relationship between the expression of TSHR and TTF-1. Unexpectedly, most of the PDCs and half of the UDCs 
showed strong TTF-1 expression regardless of TSHR expression. Previous studies reported that TTF-1 expression positively correlated with TSHR gene expression $(30,31)$. Although the discrepancy between TTF-1 and TSHR expression is an unexpected observation, it could be explained by the diverse factors which participated in TTF-1 activation, e.g. phosphorylation (32), the redox state (33), interaction with other factors and/or co-activators (34), p53 (35), or the thyroid hormone receptor $(36,37)$. Further investigation is required to clarify this matter. Therefore, we assume that the presence of TTF-1 alone is necessary, though not sufficient to produce TSHR expression.

In conclusion, we demonstrated that the poorly-differentiated components, such as the trabecular, solid and insular ones, had decreased and heterogeneous expression of the TSHR in most of the PDC cases. Furthermore, there was an inverse relationship between TSHR expression and the MIB-1 index. These findings suggest that decreased TSHR expression could affect the proliferation activity of PDC and UDC of the thyroid.

\section{Acknowledgements}

We wish to thank Ms. A. Kitazawa and Ms. A. Sumiishi for their excellent technical assistance.

\section{References}

1. Sakamoto A, Kasai N and Sugano H: Poorly differentiated carcinoma of the thyroid. A clinicopathologic entity for a highrisk group of papillary and follicular carcinomas. Cancer 52: 1849-1855, 1983.

2. Carcangiu ML, Zampi G and Rosai J: Poorly differentiated ('insular') thyroid carcinoma. A reinterpretation of Langhans' 'wuchernde Struma'. Am J Surg Pathol 8: 655-668, 1984.

3. Akslen LA and LiVolsi VA: Poorly differentiated thyroid carcinoma - it is important. Am J Surg Pathol 24: 310-313, 2000.

4. Volante M, Landolfi S, Chiusa L, Palestini N, Motta M, Codegone A, Torchio B and Papotti MG: Poorly differentiated carcinomas of the thyroid with trabecular, insular, and solid patterns: a clinicopathologic study of 183 patients. Cancer 100: 950-957, 2004.

5. Faggiano A, Caillou B, Lacroix L, Talbot M, Filetti S, Bidart JM and Schlumberger M: Functional characterization of human thyroid tissue with immunohistochemistry. Thyroid 17: 203-211, 2007.

6. Gérard AC, Daumerie C, Mestdagh C, Gohy S, De Burbure C, Costagliola S, Miot F, Nollevaux MC, Denef JF, Rahier J, Franc B, De Vijlder JJ, Colin IM and Many MC: Correlation between the loss of thyroglobulin iodination and the expression of thyroid-specific proteins involved in iodine metabolism in thyroid carcinomas. J Clin Endocrinol Metab 88: 4977-4983, 2003.

7. De Micco C, Kopp F, Vassko V and Grino M: In situ hybridization and immunohistochemistry study of thyroid peroxidase expression in thyroid tumors. Thyroid 10: 109-115, 2000.

8. Dohan O, De la Vieja A and Carrasco N: Molecular study of the sodium-iodide symporter (NIS): a new field in thyroidology. Trends Endocrinol Metab 11: 99-105, 2000.

9. Bidart JM, Mian C, Lazar V, Russo D, Filetti S, Caillou B and Schlumberger M: Expression of pendrin and the Pendred syndrome (PDS) gene in human thyroid tissues. J Clin Endocrinol Metab 85: 2028-2033, 2000.

10. Lazar V, Bidart JM, Caillou B, Mahe C, Lacroix L, Filetti S and Schlumberger M: Expression of the Na+/I- symporter gene in human thyroid tumors: a comparison study with other thyroid-specific genes. J Clin Endocrinol Metab 84: 3228-3234, 1999.
11. Civitareale D, Castelli MP, Falasca P and Saiardi A: Thyroid transcription factor 1 activates the promoter of the thyrotropin receptor gene. Mol Endocrinol 7: 1589-1595, 1993.

12. Elisei R, Pinchera A, Romei C, Gryczynska M, Pohl V, Maenhaut C, Fugazzola L and Pacini F: Expression of thyrotropin receptor (TSH-R), thyroglobulin, thyroperoxidase, and calcitonin messenger ribonucleic acids in thyroid carcinomas: evidence of TSH-R gene transcript in medullary histotype. J Clin Endocrinol Metab 78: 867-871, 1994.

13. Fabbro D, Di Loreto C, Beltrami CA, Belfiore A, Di Lauro R and Damante G: Expression of thyroid-specific transcription factors TTF-1 and PAX-8 in human thyroid neoplasms. Cancer Res 54: 4744-4749, 1994

14. Mizukami Y, Hashimoto T, Nonomura A, Michigishi T, Nakamura $S$, Noguchi $M$ and Matsukawa S: Immunohistochemical demonstration of thyrotropin (TSH)-receptor in normal and diseased human thyroid tissues using monoclonal antibody against recombinant human TSH-receptor protein. J Clin Endocrinol Metab 79: 616-619, 1994.

15. Agretti P, Chiovato L, De Marco G, Marcocci C, Mazzi B, Sellari-Franceschini S, Vitti P, Pinchera A and Tonacchera M: Real-time PCR provides evidence for thyrotropin receptor mRNA expression in orbital as well as in extraorbital tissues. Eur $\mathbf{J}$ Endocrinol 147: 733-739, 2002.

16. Tanaka K, Inoue H, Miki H, Masuda E, Kitaichi M, Komaki K, Uyama $\mathrm{T}$ and Monden Y: Relationship between prognostic score and thyrotropin receptor (TSH-R) in papillary thyroid carcinoma: immunohistochemical detection of TSH-R. Br J Cancer 76: 594-599, 1997.

17. Singh SP, McDonald D, Hope TJ and Prabhakar BS: Upon thyrotropin binding the thyrotropin receptor is internalized and localized to endosome. Endocrinology 145: 1003-1010, 2004.

18. Lyons J, Landis CA, Harsh G, Vallar L, Grunewald K, Feichtinger H, Duh QY, Clark OH, Kawasaki E, Bourne HR, et al: Two $\mathrm{G}$ protein oncogenes in human endocrine tumors. Science 249: 655-659, 1990 .

19. Parma J, Duprez L, Van Sande J, Cochaux P, Gervy C, Mockel J, Dumont J and Vassart G: Somatic mutations in the thyrotropin receptor gene cause hyperfunctioning thyroid adenomas. Nature 365: 649-651, 1993 .

20. Russo D, Arturi F, Wicker R, Chazenbalk GD, Schlumberger M, DuVillard JA, Caillou B, Monier R, Rapoport B, Filetti S and Suarez HD: Genetic alterations in thyroid hyperfunctioning adenomas. J Clin Endocrinol Metab 80: 1347-1351, 1995.

21. Spambalg D, Sharifi N, Elisei R, Gross JL, Medeiros-Neto G and Fagin JA: Structural studies of the thyrotropin receptor and Gs alpha in human thyroid cancers: low prevalence of mutations predicts infrequent involvement in malignant transformation. J Clin Endocrinol Metab 81: 3898-3901, 1996.

22. Derwahl M, Kuemmel M, Goretzki P, Schatz H and Broecker M: Expression of the human TSH receptor in a human thyroid carcinoma cell line that lacks an endogenous TSH receptor: growth inhibition by cAMP. Biochem Biophys Res Commun 191: 1131-1138, 1993.

23. Hishinuma A, Yamanaka T, Kasai K, So S, Bamba N and Shimoda SI: Growth regulation of the human papillary thyroid cancer cell line by protein tyrosine kinase and cAMP-dependent protein kinase. Endocr J 41: 399-407, 1994.

24. Ohta K, Pang XP, Berg L and Hershman JM: Growth inhibition of new human thyroid carcinoma cell lines by activation of adenylate cyclase through the beta-adrenergic receptor. J Clin Endocrinol Metab 82: 2633-2638, 1997.

25. Yano Y, Kamma H, Matsumoto H, Fujiwara M, Bando H, Hara H, Yashiro T, Ueno E, Ito K and Uchida K: Growth suppression of thyroid cancer cells by adenylcyclase activator. Oncol Rep 18: 441-445, 2007.

26. Vassart G and Dumont JE: The thyrotropin receptor and the regulation of thyrocyte function and growth. Endocr Rev 13: 596-611, 1992.

27. Postiglione MP, Parlato R, Rodriguez-Mallon A, Rosica A, Mithbaokar P, Maresca M, Marians RC, Davies TF, Zannini MS, De Felice $M$ and Di Lauro R: Role of the thyroid-stimulating hormone receptor signaling in development and differentiation of the thyroid gland. Proc Natl Acad Sci USA 99: 15462-15467, 2002.

28. Szkudlinski MW, Fremont V, Ronin C and Weintraub BD: Thyroid-stimulating hormone and thyroid-stimulating hormone receptor structure-function relationships. Physiol Rev 82: 473-502, 2002 . 
29. Abe Y, Ichikawa Y, Muraki T, Ito K and Homma M: Thyrotropin (TSH) receptor and adenylate cyclase activity in human thyroid tumors: absence of high affinity receptor and loss of TSH responsiveness in undifferentiated thyroid carcinoma. J Clin Endocrinol Metab 52: 23-28, 1981.

30. Schuppert F, Deiters S, Rambusch E, Sierralta W, Dralle H and von zur Muhlen A: TSH-receptor expression and human thyroid disease: relation to clinical, endocrine, and molecular thyroid parameters. Thyroid 6: 575-587, 1996.

31. Ros P, Rossi DL, Acebrón A and Santisteban P: Thyroidspecific gene expression in the multi-step process of thyroid carcinogenesis. Biochimie 81: 389-396, 1999.

32. Zannini M, Acebron A, De Felice M, Arnone MI, Martin-Perez J, Santisteban P and Di Lauro R: Mapping and functional role of phosphorylation sites in the thyroid transcription factor-1 (TTF-1). J Biol Chem 271: 2249-2254, 1996.

33. Arnone MI, Zannini M and Di Lauro R: The DNA binding activity and the dimerization ability of the thyroid transcription factor I are redox regulated. J Biol Chem 270: 12048-12055, 1995.
34. De Felice M, Damante G, Zannini M, Francis-Lang H and Di Lauro R: Redundant domains contribute to the transcriptional activity of the thyroid transcription factor 1. J Biol Chem 270: 26649-26656, 1995.

35. Moretti F, Farsetti A, Soddu S, Misiti S, Crescenzi M, Filetti S, Andreoli M, Sacchi A and Pontecorvi A: p53 re-expression inhibits proliferation and restores differentiation of human thyroid anaplastic carcinoma cells. Oncogene 14: 729-740, 1997.

36. Bronnegard M, Torring O, Boos J, Sylven C, Marcus C and Wallin G: Expression of thyrotropin receptor and thyroid hormone receptor messenger ribonucleic acid in normal, hyperplastic, and neoplastic human thyroid tissue. J Clin Endocrinol Metab 79: 384-389, 1994.

37. Puzianowska-Kuznicka M, Krystyniak A, Madej A, Cheng SY and Nauman J: Functionally impaired TR mutants are present in thyroid papillary cancer. J Clin Endocrinol Metab 87: 1120-1128, 2002. 